\title{
THE EFFECTIVENESS OF ONLINE BASED LEARNING DURING THE COVID-19 PANDEMIC AT PRIVATE SCHOOL IN BOGOR
}

\section{EFEKTIFITAS PEMBELAJARAN JARAK JAUH BERBASIS DARING SELAMA PANDEMI COVID 19 PADA JENJANG SEKOLAH DASAR DI BOGOR}

\author{
Arief Rachman Badrudin ${ }^{1}$, Muhammad Hidayat Ginanjar ${ }^{2}$, Wartono \\ 1, 2, ${ }^{3}$ STAI Al-Hidayah Bogor \\ e-mail: ariefbadrudin@gmail.com \\ e-mail: m.hidayatginanjar@gmail.com \\ e-mail: wartono.staia@gmail.com
}

Received: 30/07/2020, Accepted: 25/08/2020, Published: 29/08/2020

\begin{abstract}
The research is to find out the effectiveness of online distance learning at an elementary school program in Bogor. This study's approach was descriptive qualitative on survey research to 621 respondents, including the headmaster, teacher, and other stakeholders. The results showed that online distance learning at elementary was active. Therefore, the next evaluation from the headmaster, teacher, and local government supports increasing quality. Also, for improving students, competence should have good cooperation from the headmaster, teacher, and parents in service all the equipment online distance learning.
\end{abstract}

Keywords: effectiveness, distance education, online-based learning

\begin{abstract}
ABSTRAK
Penelitian ini bertujuan untuk memperoleh informasi penting tentang efektifitas pembelajaran jarak jauh (PJJ) berbasis daring pada berbagai sekolah jenjang Pendidikan Dasar di Wilayah Kota Bogor. Pendekatan penelitian menggunakan metode deskriptif kualitatif dengan jenis penelitian survey kepada 621 responden terdiri dari kepala sekolah, guru dan tenaga kependidikan. Berdasarkan data yang dianalisis, hasil penelitian menunjukkan bahwa PJJ Berbasis Daring pada Sekolah Dasar dinilai cukup efektif. Oleh karena itu sangat diperlukan evaluasi peran kepala sekolah, guru dan dukungan pemerintah Kota Bogor untuk meningkatkan kualitas pembelajaran daring. Selain itu, kerjasama yang baik antara kepala sekolah, guru dan orang tua dalam pengadaan sarana pembelajaran daring perlu ditingkatkan untuk mencapai kompetensi peserta didik.
\end{abstract}

Kata kunci: efektifitas, pembelajaran jarak jauh, berbasis daring 


\section{A. PENDAHULUAN}

Semenjak pertengahan Maret 2020 dunia pendidikan terkena dampak pandemi covid 19. Di Indonesia sendiri pemerintah sudah mengambil keputusan berupa kebijakan baru dalam pelaksanaan pembelajaran. Peserta didik yang biasanya belajar secara tatap muka di kelas dengan guru ataupun dosen, namun di saat pandemi aktifitas pembelajaran dilaksanakan di rumah secara online atau disebut sistem belajar daring di rumah masing-masing.

Berdasarkan kondisi di atas, pemerintah Kota Bogor mengeluarkan surat edaran nomor 500/75-Hukham/2020 tentang kebijakan work from home. Demikian pula kegiatan belajar diharuskan secara daring. Hal ini dilakukan untuk mencegah penularan yang meluas akibat interaksi yang masif. Physical distancing menjadi salah satu strategi harapan untuk memutus rantai penularan penyakit ini. (Daheri, Mirzon, 2020)

Dalam situasi pandemi, para pendidik (guru \& dosen) ditantang untuk berinovasi dan melakukan berbagai terobosan alternatif dalam kaitannya dengan pelaksanaan tugas pokok mengajar. Meskipun peserta didik selama pandemi berada di rumah masing-masing, namun tugas utama pendidik tetap harus berjalan, bahkan para pendidik diharapkan lebih kreatif dan inovatif mendesain pembelajaran jarak jauh dan terampil memanfaatkan media daring (online). Hal ini sesuai dengan surat edaran Menteri Pendidikan dan Kebudayaan Nomor 4 Tahun 2020 tentang pelaksanaan kebijakan pendidikan dalam masa darurat pandemi Corona Virus Desease (Covid-19). Maka, kegiatan pembelajaran di masa pandemi melalui perangkat personal computer (PC), laptop dan gadget yang terhubung dengan koneksi jaringan internet. Melalui media ini, pendidik dapat melakukan pembelajaran yang sama di waktu yang sama menggunakan grup di media sosial, diantaranya: telegram, instagram, whatsApp, Google meeting, Google Classroom, Zoom, dan lainnya.

Dengan demikian, pendidik dan peserta didik dapat melakukan pembelajaran bersama-sama dalam waktu bersamaan meskipun di tempat yang berbeda. Pendidik pun dapat memberi tugas-tugas terstruktur sesuai tujuan pembelajaran yang ditetapkan. Aktivitas pembelajaran di masa pandemi Covod-19, seluruh jenjang Pendidikan seolah dipaksa bertransformasi untuk beradaptasi melakukan pembelajaran dari rumah melalui media daring (online).

Telah dimaklumi bersama, bahwa tolok ukur keberhasilan pembangunan Negara salah satunya dilihat dari keberhasilan 
program pendidikan, mengingat dampak Pendidikan dapat melahirkan generasi penerus yang cerdas intelektual, emosional, terampil dan mandiri untuk mencapai pembangunan bangsa yang berkualitas, baik jasmani maupun ruhani, maju, dan beradab. Pembelajaran di masa pandemi tentu saja para pendidik maupun peserta didik dituntut kreatif dalam melaksanakan aktifitas pembelajaran dengan memanfaatkan fasilitas atau media pembelajaran daring. Hal ini perlu disesuaikan juga dengan jenjang pendidikan dan kebutuhan peserta didik karena dimungkinkan berdampak menimbulkan tekanan fisik maupun psikis (mental). Meskipun aktifitas pembelajaran secara daring, para pendidik tetap berharap menghasilkan capaian pembelajaran yang berkualitas. Maka disamping itu, para orang tua di rumah diharapkan bisa bekerjasama dengan pihak sekolah agar tetap mendampingi anak dengan berupaya menjadi role model dalam pendampingan belajar, baik sebagai edukator, mentor, konselor maupun sebagai partner belajar anak, terlebih bagi orang tua yang bekerja di rumah (work from home) terlebih pendampingan pada anak yang masih usia dini atau pada jenjang sekolah dasar mengingat belum meratanya diperkenalkan teknologi dalam pemanfaatan media belajar di kalangan mereka meskipun sebagian besar sudah mengenal digital namun sisi operasionalnya belum optimal diterapkan dalam aktifitas pembelajaran. Maka, pendidik pada jenjang pendidikan dasar dan menengah dituntut terus berinovasi agar peserta didik tidak jenuh, tanpa menghilangkan poin capaian pembelajaran.

Aktifitas pembelajaran secara daring di masa pandemi diharapkan menjadi budaya belajar atau suatu kebiasaan yang positif, baik di lingkungan masyarakat maupun pada setiap lembaga pendidikan pada seluruh jenjangnya meskipun tak sedikit yang mengeluhkan efektifitas pembelajaran jarak jauh secara daring (internet) dipandang kurang efektif dan kurang optimal dari aspek capaian kualitas pembelajaran maupun kualitas penguasaan dan pendalaman bahan ajar khususnya oleh peserta didik.

Kebijakan belajar di rumah khususnya di Kota Bogor diperpanjang hingga akhir Juni 2020. Kebijakan ini telah ditegaskan dalam surat edaran Nomor 016/1819Umum terkait perpanjangan masa belajar di rumah bagi seluruh peserta didik mulai jenjang TK hingga SMA/SMK hingga tanggal 13 Juli 2020. Kegiatan pembelajaran pada tahun ajaran baru 2020/2021 mengikuti kebijakan pemerintah Provinsi yaitu peraturan dari Gubernur 
menggunakan aplikasi zoom untuk para (https://www.ayobogor.com/read/2020/06/ guru.

01/7204).

Beberapa hasil penelitian menunjukkan

Terkait dengan pelaksanaan bahwa teknologi memberikan banyak pembelajaran daring di saat pandemi covidpengaruh positif dalam kegiatan 19, Pemerintah Kota Bogor sejak pertengahan Maret 2020 memberlakukan Pembatasan Sosial Berskala Besar (PSBB) di wilayah zona merah penyebaran covid19. Langkah ini dilakukan sebagai jalan keluar karena lockdown mungkin kurang efektif apalagi di saat kondisi ekonomi sedang melemah. Pemerintah juga mendirikan gugus depan penanganan covid19 untuk mengatasi penyebaran virus corona serta mendirikan rumah sakit khusus penanganan virus corona. Berbagai kebijakan yang menimbulkan pro dan kontra juga dilakukan pemerintah saat pandemi. Seperti work from home (bekerja dari rumah), study from home (belajar di rumah).

Menyikapi pelaksanaan kegiatan pembelajaran di masa pandemi ini, Dinas Pendidikan Kota Bogor terus melakukan evaluasi sistem pembelajaran dari rumah yang sudah berlangsung sejak pertengahan Maret 2020. Selain itu, Dinas Pendidikan Kota Bogor terus melakukan perbaikan terutama pada aspek peningkatan kompetensi guru melalui kegiatan workshop pembelajaran jarak jauh dengan pembelajaran, baik dalam bentuk Video, Telegram, WhatsApp, Zoom, Blog, dan lainnya. (Gheytasi, M.Azizifar, A., \& Ghowhary, 2015)

Banyak sekali masalah yang terjadi di dalam sistem pembelajaran daring, namun beberapa faktor utama masalah tersebut telah penulis rangkum dan pelajari dalam tulisan ini, diantaranya mencakup: (1) Cara guru mengetahui pembelajaran daring, (2) Sarana PJJ (Hadrware \& Software), (3) Pengetahuan guru tentang PJJ daring, (4) Kemampuan Guru dan Kepala Sekolah dalam menggunakan IT, (5) Aplikasi yang dikuasai guru dalam PJJ daring, (6) Model PJJ daring yang dilaksanakan guru, (7) Partisipasi peserta didik dan orang tua, (8) Minat dan motivasi peserta didik, (9) Kendala-kendala PJJ daring, dan (10) Frekuensi dan durasi PJJ daring yang dilakukan guru saat pandemi covid 19 .

\section{B. TINJAUAN TEORITIS}

1. Efektifitas Pembelajaran

Menurut Afifatu Rohmawati (Rohmawati, 2015), yang dimaksud efektivitas pembelajaran adalah salah satu 
dari standar mutu pendidikan yang sering kali diukur dengan tercapainya tujuan. Dapat juga diartikan sebagai ketepatan dalam mengelola suatu situasi yang biasa disebut doing the right things. Sementara itu, (Supardi, 2013) mengatakan bahwa pembelajaran yang efektif yaitu kombinasi yang meliputi; manusiawi, fasilitas, material, perlengkapan yang memadai dan terdapat prosedur yang diarahkan untuk mengubah perilaku peserta didik ke arah yang lebih baik sesuai dengan potensi dan perbedaan yang dimiliki peserta didik untuk mencapai tujuan pembelajaran yang telah ditetapkan. Sementara itu, pendapat yang lain mengemukakan bahwa pembelajaran efektif yaitu pembelajaran yang menyediakan kesempatan belajar sendiri untuk melakukan aktivitas seluas-luasnya kepada peserta didik agar mereka bisa belajar. Penyediaan kesempatan belajar sendiri dan beraktivitas seluas-luasnya diharapkan dapat membantu peserta didik dalam memahami konsep atau materi ajar yang sedang dipelajari (Hamalik, 2001: 27).

Sejalan dengan pendapat di atas, sedikit berbeda dengan pendapat (Mulyasa, 2012), yang mengatakan bahwa efektivitas pembelajaran itu yaitu ukuran keberhasilan dari suatu proses interaksi antar peserta didik maupun antara peserta didik dengan guru dalam situasi edukatif guna mencapai tujuan pembelajaran itu sendiri. Maka, efektivitas dalam pembelajaran dapat dilihat dari aktivitas peserta didiknya selama proses pembelajaran berlangsung, respon peserta didik terhadap pembelajaran dan penguasaan konsep atau materi ajar. Untuk mencapai suatu konsep pembelajaran yang efektif dan efisien perlu adanya hubungan timbal balik antara peserta didik dan guru untuk mencapai suatu tujuan secara bersama, selain itu juga harus disesuaikan dengan kondisi lingkungan sekolah, sarana dan prasarana, serta media pembelajaran yang dibutuhkan untuk membantu tercapainya seluruh aspek perkembangan peserta didik.

Penelitian yang dilakukan oleh (Oktavian \& Aldya, 2020), menyimpulkan bahwa kegiatan belajar daring menjadi sangat efektif manakala komponen esensial dalam pembelajaran itu sendiri terpenuhi yaitu interaktif, adaptif, diskursif, dan reflektif dengan elemen-elemen yang baik apabila terintegrasikan dengan lingkungan pembelajar sehingga dapat menjadi pembelajaran daring yang terintegrasi dengan lingkungan atau memenuhi komponen digital learning eco system karena dapat memunculkan perasaan positif dengan mengakomodasi gaya belajar, fleksibilitas dan pengalaman belajar peserta didik. 


\section{Pembelajaran Jarak Jauh}

Pengertian tentang pembelajaran telah banyak dijelaskan para ahli. Di antaranya dikemukakan oleh Muhammad Fajrul Bahri (Bahri, 2019), bahwa pembelajaran dimaknai sebagai proses atau cara yang dilakukan oleh seseorang agar dapat melakukan kegiatan belajar. Disamping itu, konsep pembelajaran bisa bermakna sebagai proses interaktif yang berlangsung antara guru dan peserta didik dengan tujuan untuk memperoleh ilmu pengetahuan, sikap, dan keterampilan atau skill.

Adapun konsep

mengenai pembelajaran jarak jauh (PJJ) yaitu pembelajaran yang menggunakan media sehingga memungkinkan terjadinya interaksi antara pengajar dan peserta didik atau pembelajar. Dalam konteks PJJ, antara pengajar dan pembelajar tidak tatap muka langsung, dengan kata lain antara pengajar dan pembelajar meskipun berbeda tempat dan bahkan terpisahkan oleh jarak yang sangat jauh sekalipun. (Prawiyogi, Anggi Giri, 2020)

Dalam pembelajaran jarak jauh (PJJ) terdapat beberapa faktor yang perlu diperhatikan agar sistem PJJ dapat berjalan dengan baik, yaitu; percaya diri, perhatian, pengalaman, motivasi, peralatan belajar, dan kreatifitas dalam menggunakan media, serta mampu menjalin interaksi dengan peserta didik. (Prawiyogi, Anggi Giri, 2020)

Berdasarkan beberapa hasil penelitian yang dirangkum dari penelitian Prawiyogi, dkk (Prawiyogi, Anggi Giri, 2020), bahwa PJJ memiliki beberapa keunggulan, antara lain: (1) relevansi materi ajar dengan zaman, (2) terjadinya distribusi pendidikan ke seluruh penjuru tanah air dengan daya tampung yang tidak terbatas karena tidak diperlukan ruang kelas, (3) tidak terbatas oleh waktu, (4) pembelajar untuk memilih topik bahan ajar sesuai dengan kebutuhan, (5), PJJ dapat dilaksanakan secara interaktif sehingga menarik perhatian pembelajar, dan (6) lama belajar bergantung pada kemampuan masing-masing peserta didik.

Pembelajaran dianggap akan lebih berhasil apabila objek yang dipelajari merupakan objek nyata di lingkungan sekitarnya, sehingga pentingnya pembelajaran melalui visualisasi terhadap objek di lingkungan sekitar harus direalisasikan agar dapat dengan mudah mengklarifikasi pemahaman, meningkatkan minat, dan keterlibatan nyata peserta didik. (Oktavian \& Aldya, 2020)

\section{Pembelajaran Daring}

Pembelajaran daring yang efektif dapat mengantarkan peserta didik pada tercapainya tujuan pendidikan yang ditetapkan karena dianggap efektif dalam 
mengelola situasi, terlebih dalam kondisi pandemi covid 19. Para ahli mengemukakan bahwa pembelajaran efektif adalah kombinasi yang tersusun meliputi manusiawi, material, fasilitas, perlengkapan dan prosedur diarahkan untuk mengubah perilaku peserta didik ke arah yang positif dan lebih baik sesuai dengan potensi dan perbedaan yang dimiliki peserta didik untuk mencapai tujuan pembelajaran yang telah ditetapkan (Supardi, 2013). Pendapat lainnya mengemukakan bahwa pembelajaran yang efektif adalah pembelajaran yang menyediakan kesempatan belajar sendiri atau melakukan aktivitas seluas-luasnya kepada peserta didik untuk belajar. Penyediaan kesempatan belajar sendiri dan beraktivitas seluas-luasnya diharapkan dapat membantu peserta didik dalam memahami konsep yang sedang dipelajari (Hamalik, 2004).

Pembelajaran daring bertujuan memberikan pelayanan pendidikan bermutu dalam jaringan (daring) yang bersifat masif dan terbuka untuk menjangkau peserta didik atau peminat yang lebih luas, banyak, dan terbuka (Sofyana \& Rozaq, 2019). Terkait pembelajaran daring yang efektif, maka media online dapat digunakan untuk proses pembelajaran melalui pendekatan berbasis proses, sehingga para peserta didik dapat meningkatkan kemampuan mereka, baik meliputi konten, organisasi, penanda wacana, kosa kata, konstruksi kalimat dan mekanisme penulisan. Efektivitas pembelajaran berbasis daring yaitu pembelajaran berbantuan website maupun blog (Khusniyah, Nurul Lailatul \& Hakim, 2019). Sementara itu Laksmi Dewi (Dewi, 2017) mengemukakan bahwa sistem daring dalam kegiatan belajar memiliki potensi besar menjadi salah satu alternatif pemecahan masalah-masalah dalam upaya meningkatkan pemahaman peserta didik pada kompetensi pedagogik. Begitu juga penelitian yang dilakukan oleh Eko Kuntarto (Kuntarto, 2017), menyimpulkan bahwa sistem pembelajaran berbasis daring telah memberikan pengalaman baru kepada peserta didik yang lebih menantang daripada sistem pembelajaran tatap-muka (konvensional), bahkan tidak terbatas pada waktu dan tempat belajar, melainkan dapat memberikan kebebasan pada peserta didik untuk memilih waktu yang tepat dalam belajar berdasarkan kepentingan mereka, sehingga kemampuan peserta didik menyerap materi ajar menjadi lebih tinggi dibandingkan kegiatan belajar di dalam kelas.

\section{METODE PENELITIAN}

Penelitian ini menggunakan metode survey secara online kepada responden 
berjumlah 621 orang yaitu antara lain: guru, tenaga kependidikan, dan kepala sekolah pada jenjang Sekolah Dasar Negeri di wilayah Kota Bogor yang tersebar di enam kecamatan. Data penelitian ini dianalisis dengan menggunakan metode deskriptif kualitatif. Survey dilaksanakan dengan teknik multi stage random sampling. Adapun teknik pengumpulan data menggunakan instrument kuisioner dengan aplikasi Google Forms, kemudian data diolah menggunakan google formulir. Pelaksanaan survey dan pengumpulan data dilakukan mulai tanggal 14 s.d 19 Mei 2020 M.

Berdasarkan tanggapan responden data yang paling tinggi masuk dari Kecataman Bogor Utara 20\%, Bogor Barat 18,1\%, Bogor Tengah, 16,8\%, Tanah Sareal 16,6\%, Bogor Timur, 14,7\%, dan Bogor Selatan, 14 $\%$. Sedangkan Respon berdasarkan jabatan di sekolah diperoleh data antara lain: (1) Guru Kelas $70 \%$, (2) kepala sekolah 22\%, (3) Guru Agama 4\%, (4) Guru Olahraga 3\%, dan (5) Tenaga Kependidikan $1 \%$. Berdasarkan data, responden yang terbanyak mengirim adalah guru kelas $70 \%$ dan yang paling sedikit yaitu tenaga kependidikan hanya $1 \%$. Subjek penelitian ini terkait pengalaman para responden tentang efektifitas PJJ daring saat kondisi pandemi dan pemberlakukan kebijakan
PSBB oleh pemerintah Kota Bogor yang dimulai pertengahan Maret hingga Juli 2020 .

Berdasarkan data di atas, peneliti menelaah dan mengkaji secara deskriptif terkait efektifitas pelaksanaan belajar sistem daring pada jenjang sekolah dasar di kota Bogor sejak diberlakukanya kebijakan PSBB oleh Wali Kota Bogor. Pengkajian terhadap data yang diperoleh dari responden menggunakan pendekatan deskriptif interpretatif. Pembahasan hasil penelitian menggunakan siklus interaktif didalamnya terdiri dari: display data (sajian data), dan visualisasi dan conclusion visualitation (kesimpulan).

Dalam penelitian ini, selain mengkaji secara deskriptif juga dilakukan penilaian sejawat (Peer Reviewer) untuk mengkonfirmasi temuan atau hasil penelitian guna menjaga nilai objektifitas dan validitas temuan di lapangan.

\section{PEMBAHASAN}

Pada penelitian ini dihasilkan data dari hasil survey ke sejumlah responden, antara lain: guru kelas $70 \%$, guru agama $4 \%$, guru olah raga $3 \%$, tenaga kependidikan $1 \%$, dan kepala sekolah $22 \%$ mengenai efektifitas pembelajaran jarak jauh berbasis daring selama pandemi covid-19 pada beberapa sekolah dasar di lingkungan Dinas 
Pendidikan Kota Bogor. Setelah pembelajaran jarak jauh daring dilaksanakan dalam satu semester khususnya sejak pemberlakuan kebijakan terkait Pembatasan Sosial Berskala Besar hingga tanggal 13 Juli 2020 diperoleh hasil antara lain:

1. Cara Guru Mengetahui Pembelajaran Daring

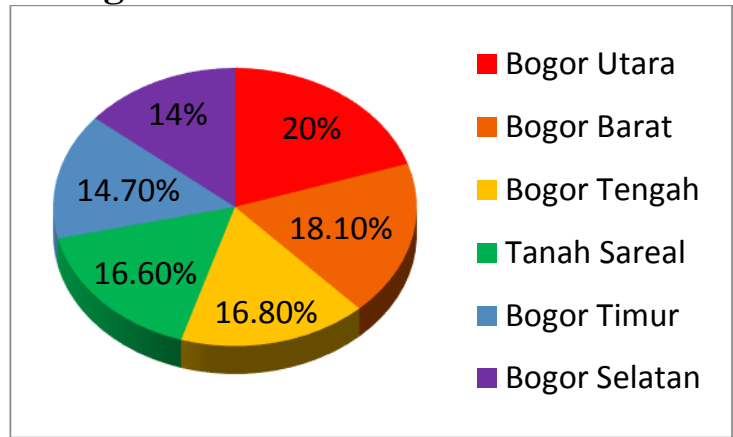

Grafik 4.1

Berdasarkan grafik di atas, dapat diketahui bahwa cara guru mengetahui tentang pembalajaran jarak jauh daring diperoleh, data paling tinggi dari Kepala sekolah dan Pengawas menunjukan selama Covid 19 komunikasi kepala sekolah dan pengawas terhadap guru pada umumnya berjalan dengan baik, baik dalam bentuk pengarahan maupun monitoring.

\section{Sarana dan Prasarana \\ Pembelajaran Daring}

Pada umumnya sekolah SD di Kota Bogor sudah memiliki sarana yang mendukung pembelajaran daring, diantaranya: Wifi, Medsos, Laptop atau Noote book. Hal ini dapat dilihat dalam grafik di bawah ini:

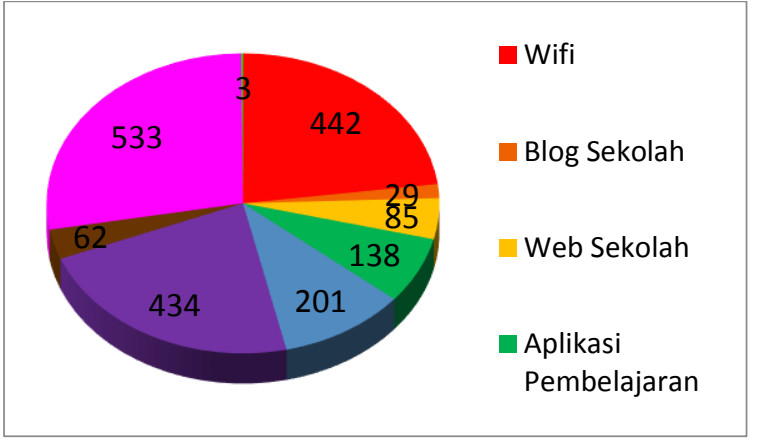

Grafik 4.2

Berdasarkan grafik di atas diketahui bahwa sejumlah Sekolah Dasar Negeri di Kota Bogor sudah memiliki sarana pembelajaran daring, diantaranya; sebanyak 442 sekolah $(71,4 \%)$ SD di Kota Bogor sudah terpasang jaringan Wifi, 49 sekolah (4,7\%) memiliki Blog, 83 sekolah $(13,7 \%)$ memiliki Website, 138 sekolah (22,3\%) sudah menggunakan aplikasi pembelajaran daring. Hal ini dinilai menjadi salah satu faktor pendukung utama suksesnya penyelenggaraan PJJ khususnya bagi para guru dalam melaksanakan tugas pokoknya sebagai pendidik dan pengajar.

\section{Pengetahuan Guru tentang PJJ}

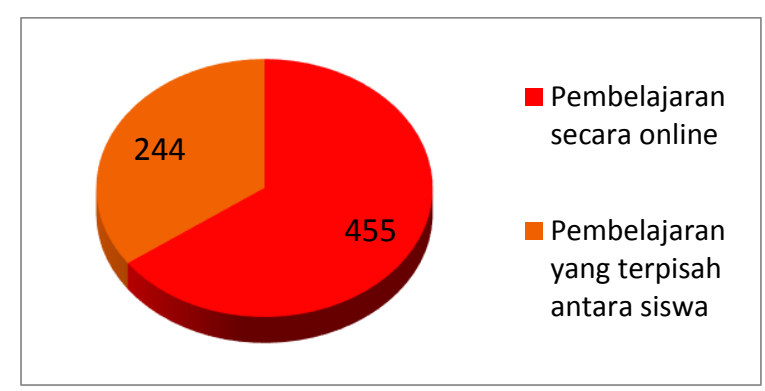

Grafik 4.3

Berdasarkan gambaran di atas, diketahui bahwa 73,5\% dari 619 responden guru menafsirkan bahwa PJJ merupakan kegiatan pembelajaran yang dilaksanakan secara online atau menggunakan jaringan 
internet dan 26,5\% responden menafsirkan PJJ merupakan pembelajaran yang terpisah antara guru dan peserta didik atau tidak difahami secara online.

\section{Kemampuan Kepala Sekolah dan Guru SD dalam Menggunakan IT}

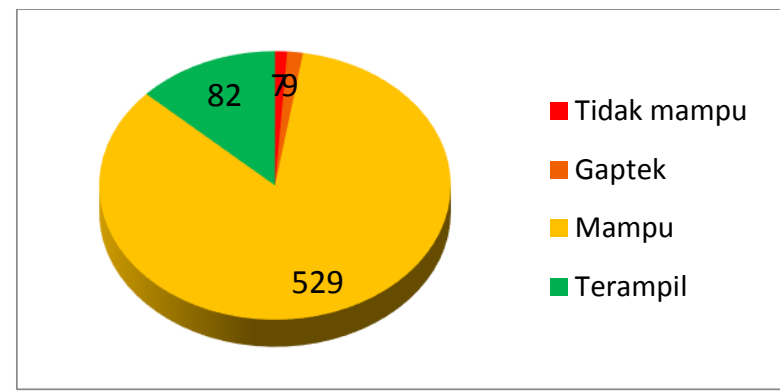

Grafik 4.4

Kepala Sekolah yang mampu atau bisa menggunakan teknologi informasi dalam pembelajaran daring sebanyak $85,5 \%$ dan yang mahir ada 13,3\%. Kepala Sekolah pada umumnya sudah mampu dalam menggunakan IT (Melek IT) antara 61-80 $\%$ ada $44,9 \%$. Selain itu, tercatat sejumlah kepala sekolah yang sudah mahir menggunakan IT antara 81-100\%, dan guru-guru yang mahir menggunakan IT ada $33,6 \%$.

\section{Aplikasi yang dikuasai Guru dalam Pembelajaran Daring}

Berdasarkan hasil survey peneliti pada sejumlah responden, diketahui bahwa aplikasi yang paling dikuasai oleh mayoritas guru yaitu media sosial. Sebagaimana digambarkan dalam grafik di bawah ini:

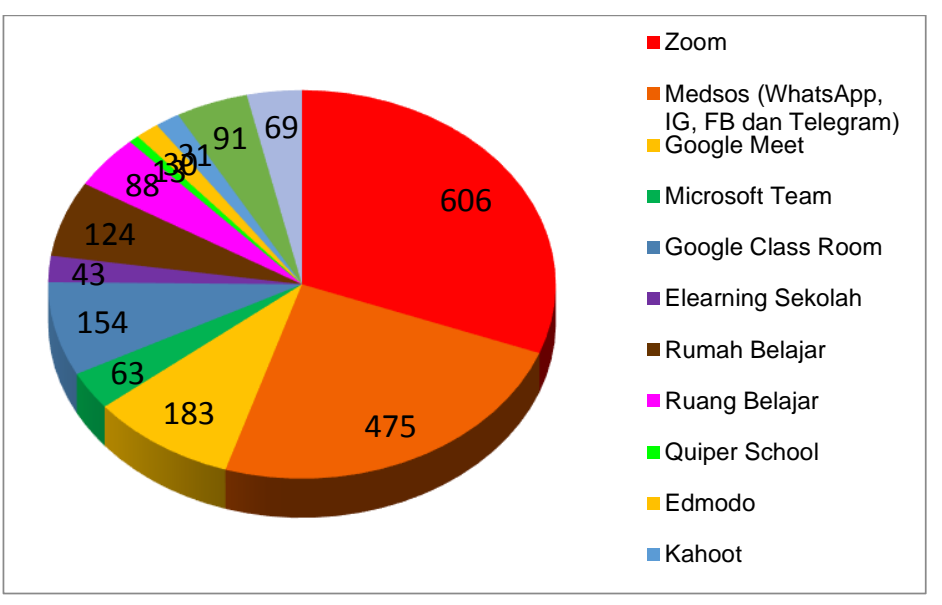

Grafik 4.5

Berdasarkan tabel diatas, terlihat bahwa 98,2\% guru menguasai media sosial, seperti; facebook, WatsApp, telegram, dan instagram. Pada jenis lainnya sebanyak 29,7\% menggunakan Google Meet, 10,2\% menggunakan Microsoft team, 25\% menggunakan Google Classroom, 7\% menggunakan E-learning, dan lainnya. Secara umum, aplikasi yang digunakan oleh para guru untuk pembelajaran jarak jauh di Sekolah Dasar masih banyak menggunakan media sosial.

\section{Model pembelajaran jarak jauh yang dilaksanakan guru}

Model pembelajaran daring yang digunakan responden selama pandemi dinilai kurang variatif. Hal ini sebagaimana dapat dilihat dalam grafik di bawah ini: 


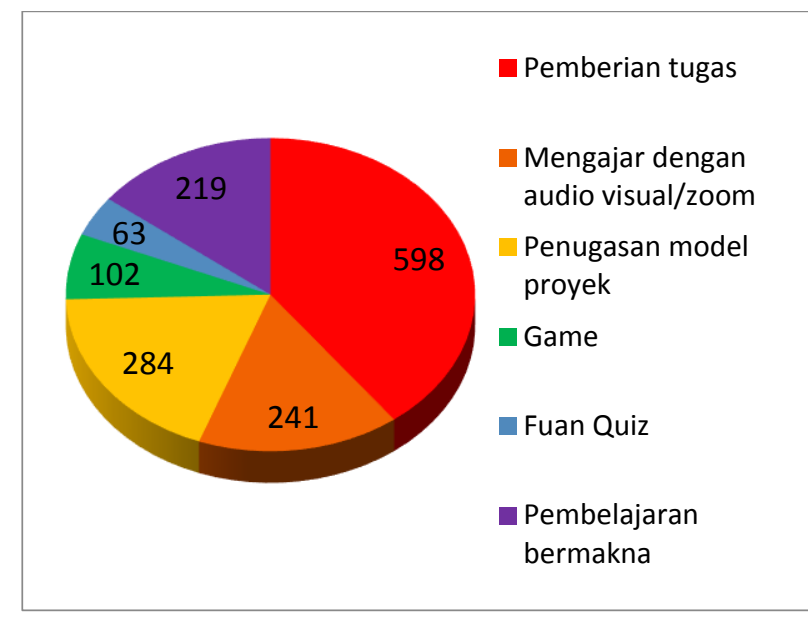

Grafik 4.6

Berdasarkan data grafik di atas, bahwa dari 619 responden, diketahui bahwa metode pembelajaran yang sering dilakukan oleh para guru lebih sering dalam bentuk memberikan tugas yaitu mencapai $96,6 \%$. Dengan perincian penugasan proyek $45,9 \%$ dan Zoom Meeting 38,9\%.

\section{Partisipasi peserta didik dan orang tua dalam pembelajaran daring}

Selama pembelajaran di masa pandemi, peserta didik dan orang tua peserta didik turut mensukseskan dalam pelaksanaan belajar daring. Sebagaimana digambarkan dalam grafik di bawah ini:

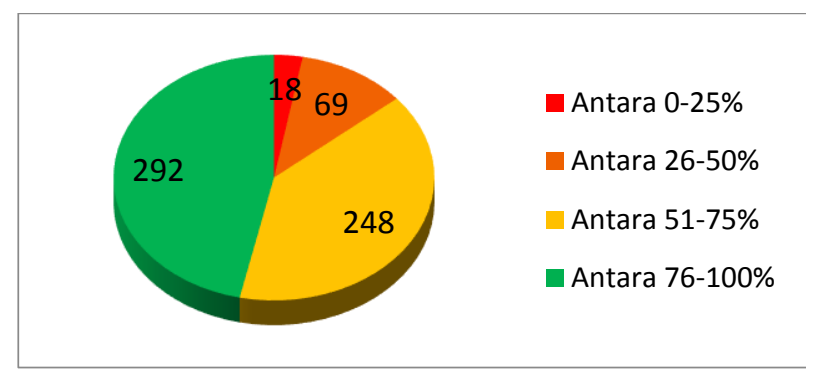

Grafik 4.7

Berdasarkan data di atas, diketahui bahwa partisipasi peserta didik dalam
PJJ cukup bervariasi. Jumlah 619 responden, dengan rata-rata $76-100 \%$ aktif $47,2 \% 50-75 \%$ ada $40,1 \%$. Dapat diketahui bahwa partisipasi peserta didik dalam PJJ daring cukup baik. Begitu juga partisipasi orang tua peserta didik dalam pembelajaran Jarak jauh sebagaimana digambarkan dalam grafik di bawah ini:

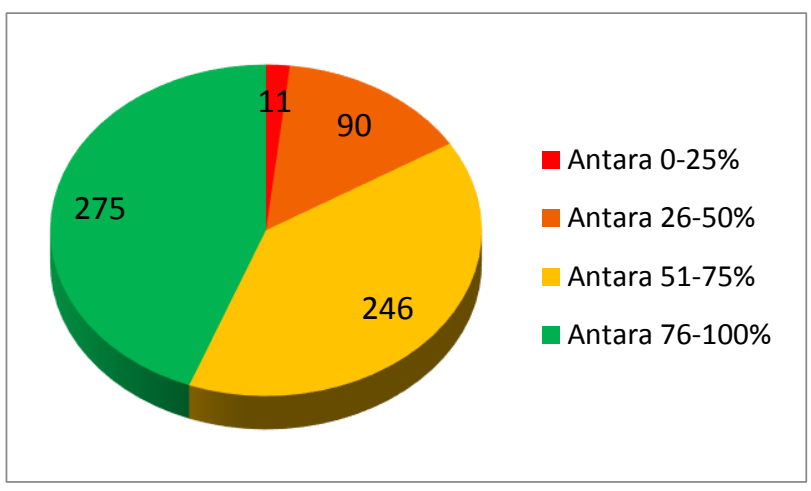

Grafik 4.8

Berdasarkan data di atas, dapat diketahui bahwa partisipasi orang tua peserta didik SD di Kota Bogor dalam pelaksanaan PJJ cukup baik. Hal ini terindikasi dari 619 responden $76-100 \%$ ada $44,6 \% 50-$ $75 \%$ ada $39,9 \%$ termasuk katagori baik.

\section{Minat dan motivasi peserta didik dalam pembelajaran daring}

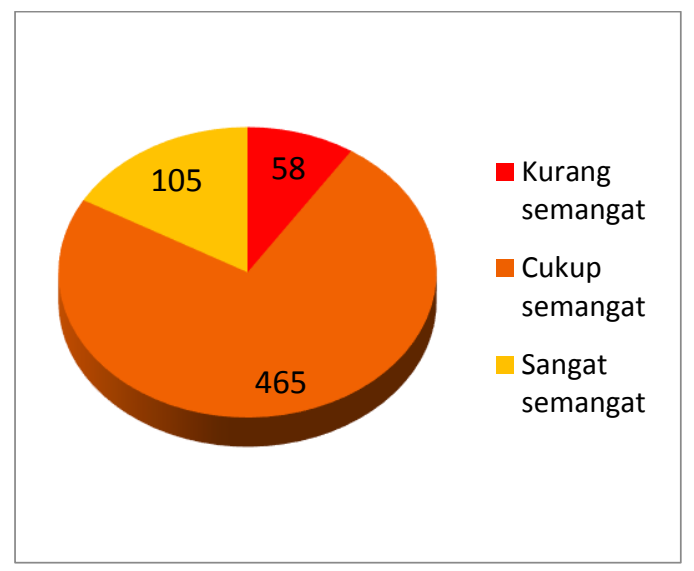




\section{Grafik 4.9}

Berdasarkan gambaran di atas, diketahui bahwa $75,1 \%$ dari 619 responden dalam mengikuti belajar daring dinilai Cukup Semangat, 17\% Sangat semangat, dan 8,7\% menyatakan kurang semangat.

\section{Kendala pembelajaran jarak jauh berbasis daring}

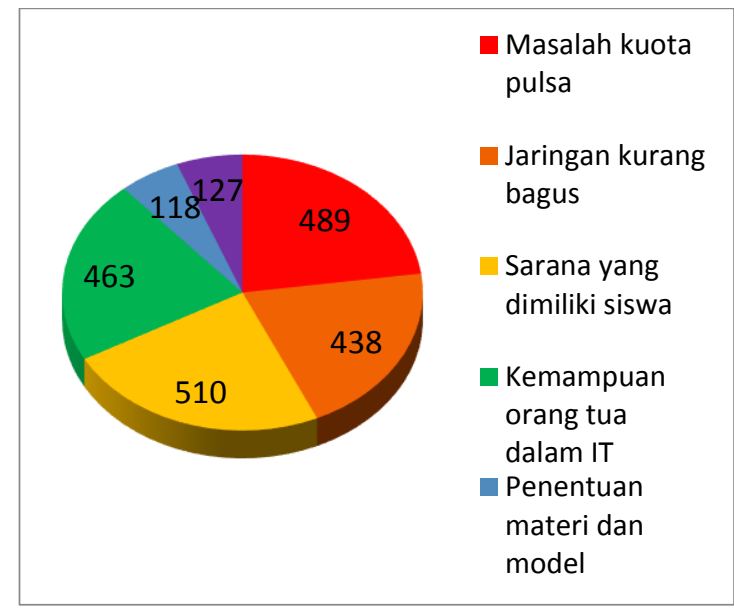

Grafik 4.10

Berdasarkan gambaran di atas, terdapat hal-hal yang menjadi kendala yang dialami guru dalam pelaksanaan pembelajaran daring. Kendala tersebut diantaranya: keterbatasan pulsa/kuota, keterbatasan sarana peserta didik, dan sebagian masih gagap dalam menggunakan teknologi pembelajaran.

\section{Frekuensi dan durasi waktu pembelajaran}

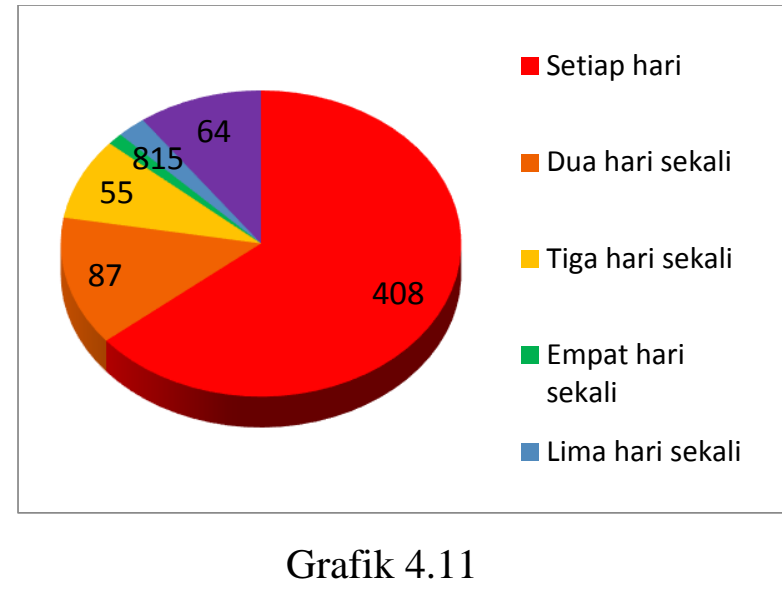

Berdasarkan gambaran di atas, diketahui bahwa $65.9 \%$ dari 619 responden guru melaksanakan PJJ setiap hari (paling tinggi). Adapun rata-rata lama waktu pembelajaran daring yang dilaksanakan oleh para guru sebagaimana tergambarkan dalam grafik di bawah ini:

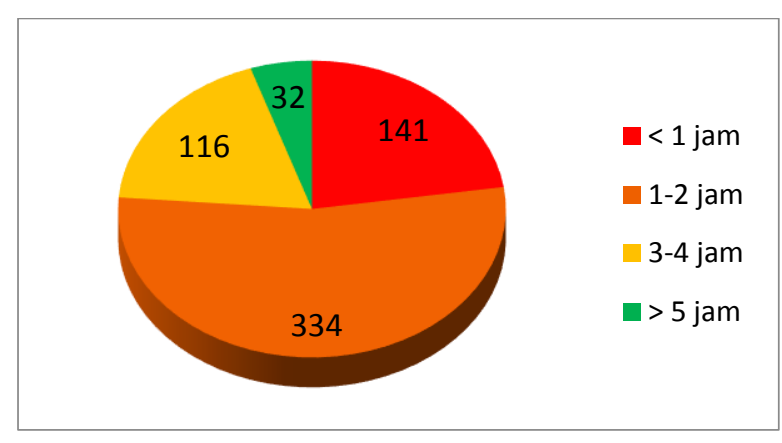

Grafik 4.12

Berdasarkan data dalam grafik di atas diketahui bahwa rata-rata lama PJJ daring yang dilaksanakan guru paling tinggi antara 1-2 jam dan menyesuaikan dengan jadwal pelajaran di sekolah. 


\section{E. KESIMPULAN}

Berdasarkan hasil penelitian dan pembahasan di atas dapat disimpulkan halhal sebagai berikut.

1. Para guru Sekolah Dasar di Kota Bogor mengetahui cara pembelajaran jarak jauh berbasis daring dan implementasinya diperoleh dari kepala sekolah dan pengawas melalui program sosialisasi, koordinasi dan monitoring yang terorganisir;

2. Dalam menyelenggarakan PJJ daring, sebagian besar sekolah jenjang SD Negeri di Kota Bogor pada umumnya sudah memiliki sarana pembelajaran daring yang cukup lengkap untuk melaksanakan PJJ daring dan sebagian lagi dalam proses mengupayakan pengadaan;

3. Kemampuan guru dan Kepala Sekolah Dasar di Kota Bogor dalam penggunaan IT untuk menunjang pembelajaran jarak jauh berbasis daring cukup memadai, namun masih perlu ditingkatkan pada beberapa hal, terutama dalam hal aplikasi teknologi informasi yang menunjang pembelajaran daring;

4. Kemampuan kepala sekolah dan para guru dalam memahami dan melaksanakan sistem PJJ daring secara umum sudah mahir, namun masih perlu ditingkatkan kualitas dan kompetensinya dalam mengembangkan metode pengajaran agar lebih variatif sehingga tidak menimbulkan kejenuhan pada peserta didik di saat proses pembelajaran berlangsung;

5. Aplikasi yang digunakan guru untuk Pembelajaran Jarak Jauh di Sekolah Dasar masih banyak menggunakan media sosial. Hal ini dimungkinkan menjadikan kegiatan belajar kurang efektif mengingat feed back yang diterima guru sangat kurang untuk menilai tingkat kemampuan peserta didik tentang pemahaman materi ajar. Hal ini sangat penting untuk diadakan evaluasi oleh sekolah secara komprehensif untuk dicarikan solusi yang lebih tepat;

6. Model pembelajaran jarak jauh berbasis daring yang dilaksanakan guru lebih sering dalam bentuk memberikan tugas-tugas. Hal ini dapat difahami mengingat peserta didik dalam mengikuti pembelajaran daring dinilai kurang aktif, kurang kreatif sehingga guru menganggap lebih apabila pendalaman materi ajar disampaikan dalam bentuk tugas terstruktur supaya peserta didik memiliki tanggung jawab 
yang baik dalam pendalaman materi ajar.

7. Partisipasi peserta didik dan orang tua dalam PJJ berbasis daring termasuk kategori cukup baik. Hal ini terindikasi berdasarkan angka partisipasi keaktipan responden peserta didik dan orang tua selama pelaksanaan PJJ daring menunjukkan angka kriteria 76100 sebesar $47,2 \%$ dari total 619 responden.

8. Minat peserta didik SD di Kota Bogor dalam mengikuti PJJ berbasis daring katagori penilaian cukup semangat, berdasarkan data responden mencapai $75,1 \%$

9. Ditemukan beberapa kendala yang dialami guru dan peserta didik dalam pelaksanaan PJJ daring, diantaranya: keterbatasan sarana atau media daring, keterbatasan kuota, dan sebagian masih gagap teknologi pembelajaran.

10. Frekuensi dan lama PJJ daring yang dilaksanakan guru pada saat pandemi covid 19 masuk katagori cukup tinggi $(65,9 \%)$ dengan lama pembelajaran antara 1-2 jam pelajaran.

\section{REKOMENDASI}

1. Dinas Pendidikan Kota Bogor masih perlu meningkatkan kualitas model
PBJJ, diantaranya; perlu menyusun pedoman atau panduan pembelajaran jarak jauh yang lebih lengkap dan jelas, menyelenggarakan pelatihan atau workshop tentang pembelajaran jarak jauh kepada guru dan kepala sekolah, adanya sosialisasi secara terbuka dan umum tentang pembelajaran jarak jauk kepada orang tua dan masyarakat.

2. Dibutuhkan bantuan khusus untuk guru dalam menunjang suksesnya tugas mengajar daring seperti pemberian tunjangan/bantuan pulsa/kuota, dan bantuan lainnya.

3. Dibutuhkan kerjasama dengan orang tua dalam pengadaan sarana pembelajaran jarak jauh untuk para peserta didik.

\section{DAFTAR PUSTAKA}

Bahri, M. F. (2019). Kemampuan Berpikir Kritis Menggunakan Tes Terintegrasi Agama dan Sains dalam Pembelajaran PAI di SMA. Edukasi Islami: Jurnal Pendidikan Islam, 8(02).

Daheri, Mirzon, D. (2020). Efektifitas WhatsApp sebagai Media Belajar Daring. BASICEDU, 4(04).

Dewi, L. (2017). Rancangan Program Pembelajaran Daring Di Perguruan Tinggi: Studi Kasus Pada Mata Kuliah Kurikulum Pembelajaran Di Universitas Pendidikan Indonesia. Jurnal Edutect, 16(02). 
Gheytasi, M.Azizifar, A., \& Ghowhary, H. (2015). The Efect of Smartphone on the Reading Comprehension Proficiency of Iranian EFL Learners. Procedia-Social and Behavioral Sciences, 119, 225-230.

Hamalik, O. (2010). Psikologi Belajar dan Mengajar (8th ed.). Sinar Baru Algensindo.

Khusniyah, Nurul Lailatul \& Hakim, L. (2019). Efektifitas Pembelajaran Berbasis Daring: Sebuah Bukti Pada Pembelajaran Bahasa Inggris. Tatsqif: Jurnal Pemikiran Dan Penelitian Pendidikan, 17(01).

Kuntarto, E. (2017). Keefektifan Model Pembelajaran Daring Dalam Perkuliahan Bahasa Indonesia di Perguruan tinggi. Journal Indonesian Language Education and Literature, $3(01)$.

Mulyasa, E. (2012). Manajemen Pendidikan Anak Usia Dini (Pertama). Remaja Rosdakarya.

Oktavian, R., \& Aldya, R. F. (2020). Efektivitas Pembelajaran Daring Terintegrasi di Era Pendidikan 4.0. Didaktis: Jurnal Pendidikan Dan Ilmu Pengetahuan, 20(02). https://doi.org/10.30651/didaktis.v20i 2.4763

Prawiyogi, Anggi Giri, D. (2020). Efektifitas Pembelajaran Jarak Jauh Terhadap Pembelajaran Peserta didik di SDIT Purwakarta. JPD: Jurnal Pendidikan Dasar, 11(01).

Rohmawati, A. (2015). Efektivitas Pembelajaran. Jurnal Pendidikan Usia Dini, 9(1).
Sofyana, L., \& Rozaq, A. (2019). Pembelajaran Daring Kombinasi Berbasis WhatsApp Pada Kelas Karyawan Prodi Teknik Informatika Universitas PGRI Madiun. Jurnal Nasional Pendidikan Teknik Informatika (JANAPATI), 8(01). https://doi.org/10.23887/janapati.v8i1. 17204

Supardi. (2013). Sekolah Efektif, Konsep Dasar dan Praktiknya. Rajawali Pers. 
